\title{
Prevention of Flower Abscission in Bell Pepper
}

\author{
H.C. Wien'and Yiping Zhang ${ }^{2}$ \\ Department of Fruit and Vegetable Science, Cornell University, Ithaca, NY 14853
}

Additional index words. low light, NAA, silver thiosulfate, ethylene, auxin

\begin{abstract}
A series of greenhouse experiments was conducted with 'Shamrock' bell pepper (Capsicum annuum L.) to gain insight into the flower abscission mechanism and to investigate methods to reduce reproductive structure abscission due to low light intensity. Foliar sprays of STS reduced stress-induced abscission. Application of the synthetic auxin NAA to the ovary substituted for pollination to effect fruit set under nonstress conditions, but did not improve

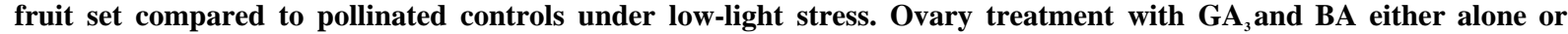
combined with NAA had similar results to NAA treatment alone. Foliar sprays of NAA or CPA also did not improve fruit set under low-light stress conditions. Application of NAA in an aqueous paste to the abscission zone prevented abscission but inhibited fruit growth. Taken together, the results indicate that stress-induced abscission is not prevented by auxin application to the ovary or foliage. The interaction of ethylene and auxin in reproductive structure abscission under stress conditions requires further investigation. Chemical names used: 6-benzylaminopurine (BA), p-chlorophenoxy acetic acid (CPA), gibberellic acid (GA,), silver thiosulfate (STS).
\end{abstract}

The abscission of reproductive structures in bell pepper is a major pepper production problem in the northeastern United States and is most often caused by periods of high temperatures (Wien, 1990). The abscission mechanism appears to be similar to that identified for cotton leaves (Beyer and Morgan, 1971) and Begonia flower buds (Hanisch ten Cate and Bruinsma, 1973). During normal growth, auxin produced by the reproductive organ prevents the formation of an abscission zone, located in pepper at the base of the pedicel. When stress is imposed, i.e., from a period of low light intensity, ethylene is generated by the reproductive structure (Wien et al., 1989). Research with herbaceous and woody plants indicates that ethylene reduces auxin levels in the abscising organ, inhibits polar auxin transport, and acts directly at the pedicel base to separate the cells in the abscission zone (Morgan, 1984; Riov et al., 1984; Sagee et al., 1990).

It maybe possible to prevent abscission by augmenting auxin production of reproductive structures under conditions of low fruit set. Treatment of flowers with auxin has improved fruit set of tomato (Mann and Minges, 1949; Osborne and Went, 1953) and of pepper (Silveria et al., 1986) in cool weather. Auxin flower sprays, however, have been less successful in preventing abscission in tomato under higher temperatures, particularly when combined with low light intensities (Osborne and Went, 1953).

Another approach to preventing abscission might be to inhibit ethylene production or ethylene action. Evidence from some crops suggests that this technique might show promise for pepper. The ethylene synthesis inhibitor aminoethyoxyvinylglycine (AVG) increased fruit set of apple when applied at bloom (Walsh and Faust, 1982). Inhibition of ethylene action with STS resulted in reduced flower bud abscission in lily (van Meeteren and de Proft, 1982) and hibiscus (Thaxton et al., 1988) and inhibited petal abscission of geranium, Calceolaria, and Bougainvillea (Cameron and Reid, 1983).

The present experiments were conducted to explore methods

Received for publication 2 July 1990. Fruit and Vegetable Science Paper no. 7. The partial support of this research by Federal Hatch Act funds (Project no. NYC-161425, USDA) is gratefully acknowledged. Seeds of 'Shamrock' were kindly donated by Asgrow Seed Co. The cost of publishing this paper was defrayed in part by the payment of page charges. Under postal regulations, this paper therefore must be hereby marked advertisement solely to indicate this fact.

'Associate Professor.

'Visiting Scholar. by which stress-induced pepper flower abscission could be inhibited and to gain further evidence on the abscission mechanism. Stress was imposed using heavy shade, since this technique gave abscission results similar to subjecting the plants to high temperatures and was easier to apply (Wien, 1990; Wien et al., 1989).

\section{Materials and Methods}

Plant culture. 'Shamrock' pepper plants for these greenhouse experiments were started from seed sown in a peat-vermiculite artificial soil mix in Todd Planter (Speedling, Sun City, Fla.) flats of 80-ml individual cell volume. After 6 to 8 weeks growth at $27 / 21 \mathrm{C}$ (day/night), seedlings were transplanted to 2-liter plastic pots of $15-\mathrm{cm}$ diameter filled with the same artificial soil mix. Plants were 65 to 85 days old when treatments were begun.

Shade treatments consisted of covering the greenhouse bench with a canopy of polypropylene shadecloth that blocked $80 \%$ of incident radiation. During midsummer (Expt. 1), it was necessary to use two layers of this cloth, reducing light by $96 \%$, to induce abscission, since the $80 \%$ shade treatment resulted in little abscission in preliminary experiments. Air temperatures were similar inside and outside the enclosure during the day, but were 1 to $2 \mathrm{C}$ higher at night. Solar radiation values were obtained from a meteorological station located $1 \mathrm{~km}$ from the greenhouse and are not corrected for shade influence of the greenhouse structure.

In each experiment, only a single shade structure was used. Plants were randomly arranged within it and in the unshaded area. After shading, all plants were randomly arranged on one bench. Individual plants comprised the experimental units, and statistical significance between treatments was determined by calculating treatment standard errors.

Auxin foliar sprays Expt. 1). The experiment was conducted to determine if auxin sprays applied at flowering could reduce or prevent flower abscission induced by low-light stress. Plants were subjected to $96 \%$ shade for 1 week in a $27 / 17 \mathrm{C}$ greenhouse during August to induce flower abscission. Photosynthetic photon flux values averaged $399 \mu \mathrm{mol} \cdot \mathrm{s}^{-1} \cdot \mathrm{m}^{-2}$ for unshaded plants during the shade period. Before shading, three open flowers and seven flower buds ranging in diameter from 5 to $10 \mathrm{~mm}$ were tagged on each of five plants per treatment. All flowers were pollinated at anthesis, and observations were taken daily to note abscission dates of all tagged reproductive structures. Foliar sprays of 0,10 , or $100 \mu \mathrm{M}$ NAA or 10 or $100 \mu \mathrm{M}$ CPA were applied to run-off at the start of the shade period. Ivory liquid 
detergent at $0.1 \%$ concentration was added as a wetting agent to all solutions. Final abscission data were taken 8 days after the end of the shade treatment.

NAA application to ovary (Expts. 2 and 3). Two experiments compared the efficacy of NAA, applied through a wick directly to the flower, on fruit set of emasculated flowers under full light and $80 \%$ shade. Wicks consisting of single strands of embroidery cotton were inserted between the calyx and the ovary, with the other end in 1.5-ml microcentrifuge tubes filled with hormone solution and attached to the plant (Wien et al., 1989). Treatments consisted of a water-treated pollinated control and emasculation combined with application of water or 1 or $10 \mu \mathrm{M}$ NAA. Emasculation was performed by removing anthers and style 1 day before anthesis. For pollinated controls, pollen was applied to the style and anthers were subsequently removed. Four buds were treated per plant, with five plants per treatment. Plants were placed either under $80 \%$ shade for 5 and 7 days in Expts. 2 and 3, respectively, or left unshaded in a 27/21C greenhouse. Abscission and fresh weight of the treated flowers and fruits were determined 2 weeks after treatments were begun.

Growth promoter application to ovary (Expt. 4). The development of reproductive structures under low-light stress may fail because these structures are weak competitors compared to vegetative organs on the plant. Tomato clusters that would normally abort under low-light conditions could be stimulated to continue development by the addition of mixtures of gibberellin and cytokinin to the inflorescence (Kinet et al., 1978). The experiment investigated the effect of $\mathrm{GA}_{3}$ and $\mathrm{BA}$ application to the ovary with or without NAA, using the wick system. Five $\mu \mathrm{M} \mathrm{G} \mathrm{A}_{3}$ and $5 \mu \mathrm{MBA}$ were applied with or without $1 \mu \mathrm{M}$ NAA; there also were emasculated and pollinated controls. Plants were either placed in $80 \%$ shade for 1 week or left unshaded. Four buds were treated per plant, with four plants per treatment. Abscission and fruit weight data were taken 2 weeks after the start of the treatments.

NAA paste experiments (Expts. 5 and 6). Application of NAA directly to the abscission zone in an aqueous paste was compared to foliar sprays of the ethylene action inhibitor STS in two experiments. The NAA paste consisted of a mixture of $27 \%$ lanolin, 5\% stearic acid, 2\% morpholine, and $66 \%$ water. The nonaqueous components were heated and mixed, and an aqueous solution of the appropriate amount of NAA was then stirred in before the mixture cooled. Paste treatments were applied to two to four open flowers and five to seven buds per plant. Treatments consisted of a water paste control and NAA at $0.01 \%$ and $0.1 \%(0.05 \%$ in Expt. 6) applied to the bud and flower pedicel at $2 \mathrm{mg}$ /inflorescence. In other treatments, foliar sprays of STS at 1 or $5 \mathrm{~mm} \mathrm{Ag} \mathrm{g}^{+}$were applied to run-off at the start of the experiment and repeated 3 days later. The STS solution consisted of a 1:4 molar ratio of silver nitrate and sodium thiosulfate (Reid et al., 1980) to which $0.1 \%$ liquid detergent was added as a wetting agent. All flowers were hand-pollinated at anthesis. Five plants per treatment were subjected to $80 \%$ shade for 1 week and three plants were left unshaded. The experiments were conducted in a greenhouse set at 27/21C during April and May. Abscission data and fruit fresh weights at the tagged nodes were taken 2 weeks after the end of the shading period.

\section{Results and Discussion}

Auxin foliar sprays. Foliar sprays of the synthetic auxins NAA and CPA had no significant effect on fruit set of the unshaded plants (Table 1). Treatment of shaded plants with NAA increased the amount and rate of abscission compared to shaded
Table 1. Effect of foliar sprays of two synthetic auxins on flower and flower bud abscission of 'Shamrock' peppers grown under greenhouse conditions in full light or shaded conditions (Expt. 1).

\begin{tabular}{|c|c|c|c|c|}
\hline \multirow[b]{2}{*}{ Foliar spray } & \multirow{2}{*}{$\begin{array}{c}\text { Concn } \\
(\mu \mathrm{M})\end{array}$} & \multicolumn{2}{|c|}{ Abscission $(\%)^{z}$} & \multirow{2}{*}{$\begin{array}{c}\text { Abscission } \\
\text { DAS }^{y}\end{array}$} \\
\hline & & Unshaded & $96 \%$ Shade & \\
\hline $\mathrm{H}_{2} \mathrm{O}$ & & 0 & $24.6 \pm 9.5$ & $9.1 \pm 2.2$ \\
\hline \multirow[t]{2}{*}{ NAA } & 10 & $2.0 \pm 4.5$ & $58.0 \pm 16.4$ & $6.3 \pm 1.5$ \\
\hline & 100 & 0 & $82.4 \pm 14.8$ & $6.5 \pm 1.6$ \\
\hline \multirow[t]{2}{*}{ CPA } & 10 & $2.0 \pm 4.5$ & $50.8 \pm 25.9$ & $7.6 \pm 1.8$ \\
\hline & 100 & 0 & $49.2 \pm 20.2$ & $10.4 \pm 2.4$ \\
\hline
\end{tabular}

${ }^{2}$ Determined 14 days after the start of a 7 -day $96 \%$ shade treatment. Mean \pm SE.

${ }^{y}$ Abscission time, days after experiment started, for shaded plants only. Mean \pm SE.

controls. CPA sprays had effects similar to NAA, but at 100 $\mu \mathrm{M}$, abscission rates slowed to that of the shaded controls. The reason for this differential response to the two synthetic auxins is not known. In spite of the reduction of incident radiation by $96 \%$, shaded control plants abscised only $25 \%$ of their reproductive structures, indicating that the stress level imposed was moderate.

NAA application to ovary. In the previous experiment, all fruits were pollinated at anthesis, making it impossible to determine if NAA application could substitute for pollination and bring about the growth of parthenocarpic fruit. Accordingly, the present experiments included both pollinated and emasculated controls, and the NAA treatments were applied to emasculated flowers on plants subsequently subjected to low-light stress or left unshaded. Shading of the pollinated control plants increased flower abscission (Table 2) in Expt. 2 but not in Expt. 3, indicating the marginal level of low-light stress applied. Emasculation resulted in nearly complete abscission in both expedients. NAA applied to the ovary through the wick system reduced abscission, more markedly under full than under low-light conditions. Fruits set parthenocarpically under full light tended to weigh less than the controls (Table 2) and were broader in shape, without the central core present in seeded fruits. Seeded fruits on shaded plants weighed only half as much as those on unshaded controls and were similar in weight to parthenocarpic fruit induced by NAA.

Growth promoter application to ovary. The infusion of $\mathrm{GA}_{3}$ and BA brought about parthenocarpic set under full light conditions, but did not increase fruit set percentage significantly above that of pollinated controls on shaded plants (Table 3). Similar results were obtained when NAA was added to the $\mathrm{GA}_{3}$ and BA solution. Fruit weight was significantly reduced by $\mathrm{GA}_{3}$ plus BA treatment under both light conditions. Addition of NAA restored fruit weight to nearly that of pollinated fruits. Parthenocarpic set of flowers with concomitant fruit weight reduction has also been noted with $\mathrm{GA}_{3}$-induced fruit set in tomato (Asahira et al., 1967).

NAA paste application. Previous work indicated that abscission of pepper pedicels from which buds had been removed could be prevented by NAA application (Wien et al., 1989). Auxin paste applied to the pedicel should, therefore, prevent stress-induced abscission of flowers and flower buds. However, although NAA paste applied to the pedicel partly reduced lowlight stress-induced abscission, the fruits formed remained small (Table 4). At the higher NAA concentrations used, a callus 2 to $5 \mathrm{~mm}$ in diameter formed at the point of auxin application, and bud and flower tissue stopped growing and frequently became necrotic. Fruits on unshaded plants given the same treat- 
Table 2. Effect of emasculation, NAA infusion, and plant shading on abscission of pepper flowers and weight of retained fruit. ${ }^{2}$ Shade duration was 5 days for Expt. 2, 7 days for Expt. 3, reducing light by $80 \%$.

\begin{tabular}{|c|c|c|c|c|c|c|}
\hline \multirow[b]{2}{*}{ Pollination } & \multirow{2}{*}{$\begin{array}{l}\text { Shade } \\
\text { level }\end{array}$} & \multirow{2}{*}{$\begin{array}{l}\text { NAA concn } \\
(\mu M)\end{array}$} & \multicolumn{2}{|c|}{ Abscission (\%) } & \multicolumn{2}{|c|}{ Wt/fruit (g) } \\
\hline & & & Expt. 2 & Expt. 3 & Expt. 2 & Expt. 3 \\
\hline Yes & 0 & 0 & $25 \pm 18$ & $5 \pm 11$ & $22.0 \pm 3.7$ & $24.3 \pm 5.8$ \\
\hline \multirow[t]{3}{*}{ No } & 0 & 0 & $90 \pm 14$ & $95 \pm 11$ & --- & -- \\
\hline & 0 & 1 & $45 \pm 37$ & $20 \pm 21$ & $14.8 \pm 6.2$ & $15.9 \pm 4.1$ \\
\hline & 0 & 10 & $20 \pm 21$ & $0 \pm 0$ & $15.6 \pm 3.6$ & $19.6 \pm 3.6$ \\
\hline Yes & $80 \%$ & 0 & $80 \pm 32$ & $15 \pm 14$ & -- & $10.1 \pm 6.3$ \\
\hline \multirow[t]{3}{*}{ No } & $80 \%$ & 0 & $100 \pm 0$ & $100 \pm 0$ & --- & --- \\
\hline & $80 \%$ & 1 & $95 \pm 11$ & $95 \pm 11$ & --- & --- \\
\hline & $80 \%$ & 10 & $70 \pm 32$ & $45 \pm 37$ & $\ldots$ & $14.0 \pm 5.5$ \\
\hline
\end{tabular}

${ }^{2} \bar{M}{ }^{-}$ean \pm SE, measured ${ }^{-}{ }^{-}$week̄s after start of experiment.

Table 3. Effect of the growth promoters NAA, GA, and BA applied to individual flowers in a wick system on abscission percentage and size of retained fruit (Expt. 4). ${ }^{\mathrm{z}}$

\begin{tabular}{|c|c|c|c|c|c|c|}
\hline \multirow[b]{2}{*}{ Pollination } & \multirow[b]{2}{*}{ Chemical } & \multirow{2}{*}{$\begin{array}{l}\text { Concn } \\
(\mu \mathrm{M})\end{array}$} & \multicolumn{2}{|c|}{ Abscission (\%) } & \multicolumn{2}{|c|}{ Wt/fruit (g) } \\
\hline & & & Unshaded & $80 \%$ Shade & Unshaded & $80 \%$ Shade \\
\hline $\begin{array}{l}\text { Yes } \\
\text { No }\end{array}$ & $\begin{array}{c}\mathrm{H}_{2} \mathrm{O} \\
\mathrm{H}_{2} \mathrm{O} \\
\mathrm{GA}_{3}+\mathrm{BA} \\
\mathrm{GA}_{3}+\mathrm{BA}+\mathrm{NAA}\end{array}$ & $\begin{array}{c}5+5 \\
5+5+1 \\
\end{array}$ & $\begin{aligned} 6 & \pm 12 \\
94 & \pm 12 \\
12 & \pm 14 \\
0 & \end{aligned}$ & $\begin{aligned} & 31 \pm 31 \\
& 100 \pm 0 \\
& 50 \pm 35 \\
& 56 \pm 12 \\
&\end{aligned}$ & $\begin{aligned} & 22.0 \pm 5.1 \\
&- \\
& 7.8 \pm 3.7 \\
& 18.7 \pm 7.8 \\
&\end{aligned}$ & $\begin{aligned} & 18.5 \pm 5.6 \\
&- \\
& 4.9 \pm 0.9 \\
& 12.0 \pm 5.5 \\
&\end{aligned}$ \\
\hline
\end{tabular}

${ }^{\mathrm{z}}$ Measured 14 days after the start of a 7 -day $80 \%$ shade treatment. Mean \pm SE.

Table 4. Effect of auxin paste applied to the pedicel or of STS foliar spray on abscission and fresh weight of the retained fruit for 'Shamrock' pepper subjected to a 7-day $80 \%$ shade treatment or left unshaded (Expts. 5 and 6).

\begin{tabular}{|c|c|c|c|c|c|c|}
\hline \multirow[b]{2}{*}{ Treatment } & \multicolumn{2}{|c|}{ Abscission (\%) } & \multicolumn{4}{|c|}{ Wt/fruit (g) } \\
\hline & Unshaded & $80 \%$ Shade & Unshaded & 80 & $6 \mathrm{Sh}$ & \\
\hline \multicolumn{7}{|c|}{ Expt. 5} \\
\hline Control & $21 \pm 18$ & $97 \pm 8$ & $22 \pm$ & 20 & \pm & 9 \\
\hline NAA paste & & & & & & \\
\hline $0.01 \%$ & $20 \pm 15$ & $58 \pm 21$ & $23 \pm$ & 7 & \pm & 5 \\
\hline $0.1 \%$ & 0 & $5 \pm 7$ & $21 \pm 4$ & 0.1 & \pm & 0.03 \\
\hline \multicolumn{7}{|l|}{ STS spray } \\
\hline $1 \mathrm{mM}$ & $7 \pm 6$ & $73 \pm 18$ & $15 \pm$ & 18 & \pm & 2 \\
\hline $5 \mathrm{mM}$ & $3 \pm 6$ & $34 \pm 26$ & $12 \pm 2$ & 9 & \pm & 4 \\
\hline \multicolumn{7}{|c|}{ Expt. 6} \\
\hline Control & $8 \pm 14$ & $95 \pm 7$ & $46 \pm$ & 21 & \multicolumn{2}{|c|}{ \pm 11} \\
\hline NAA paste & & & & & & \\
\hline $0.01 \%$ & $4 \pm$ & $39 \pm 20$ & $43 \pm$ & 12 & \pm & \\
\hline $0.05 \%$ & 0 & $5 \pm 7$ & $31 \pm 5$ & 3 & \pm & 3 \\
\hline \multicolumn{7}{|l|}{ STS spray } \\
\hline $1 \mathrm{mM}$ & $3 \pm 6$ & $53 \pm 26$ & $40 \pm 4$ & 10 & \pm & 6 \\
\hline $5 \mathrm{mM}$ & $10 \pm 11$ & $10 \pm 14$ & $35 \pm 11$ & 11 & \pm & 3 \\
\hline
\end{tabular}

${ }^{\mathrm{z}}$ Mean \pm SE, measured 2 weeks after shade removal.

ments grew normally, although callus again developed at the point of NAA application. The localized auxin application probably stimulated transport of assimilates to that spot (Hayes and Patrick, 1985; Seth and Wareing, 1967). In the low-light-stressed plants, this new sink may have been stronger than the developing fruit, preferentially diverting the reduced supply of assimilates away from the fruit and leading to its senescence. Fruits developing on unshaded plants might have continued to be strong sinks in spite of auxin application to the pedicel base.

Foliar application of STS reduced abscission of flowers and flower buds induced by low-light stress (Table 4). Fruit fresh weight was lower in treated than in control plants in both shaded
(5 $\mu \mathrm{M}$ STS only) and unshaded plants. The fruit growth inhibition by STS may be related to the inhibitory effect of the $\mathrm{Ag}^{+}$ ion on invertase (Mealor and Townshend, 1968), a key enzyme in growth of fruits (Yelle et al., 1988). Seed production was not inhibited by STS application, and fruits retained by the treated plants contained developing seeds.

The results of these experiments partially support the theory that the hormonal control mechanism of abscission proposed for leaves by Beyer and Morgan (1971) also holds true for pepper reproductive structures. Synthetic auxin applied to the ovary reduced abscission of emasculated flowers (Table 2), and the ethylene action inhibitor STS prevented fruit abscission induced by low-light stress (Table 4). However, auxin foliar sprays increased stress-induced abscission of reproductive structures (Table 1), in contrast to similar treatments that effectively prevented leaf abscission (Hall, 1952). In pepper subjected to low-light stress, NAA foliar sprays may induce the plant to generate ethylene, as has been shown for other species (Walsh et al., 1979; Yang, 1980). The failure of ovary applications of NAA or the growth promoters $\mathrm{GA}_{3}$ and $\mathrm{BA}$ to prevent abscission of the reproductive structures also may be based on a lack of inhibition of stress-generated ethylene. Further work is needed to elucidate the interaction of ethylene and growth promoters in stress-induced abscission and to determine if auxin and STS treatments could be combined to improve fruit set and maintain fruit weight.

From a practical standpoint, STS spray could be useful in reducing flower and flower bud loss due to stress in pepper. Because silver is a heavy metal, its use is unlikely to be safe on crops for human consumption (Veen, 1987), but the method might find application in pepper seed production and breeding programs.

\section{Literature Cited}

Asahira, T., Y. Takeda, T. Nishio, M. Hirabayashi, and Y. Tsukamoto. 1967. Studies on fruit development in tomato. I. Ovule development and content of diffusible auxin in synthetic auxin- and 
gibberellin-induced parthenocarpic tomato fruits in relation to their development. Mere. Res. Inst. Food Sci. Kyoto Univ. 28:47-74.

Beyer, E. M., Jr., and P. W. Morgan. 1971. Abscission. The role of ethylene modification of auxin transport. Plant Physiol. 48:208-212.

Cameron, A.C. and M.S. Reid. 1983. Use of silver thiosulfate to prevent flower abscission from potted plants. Scientia Hort. 19:373378.

Hall, W.C. 1952. Evidence on the auxin-ethylene balance hypothesis of foliar abscission. Bet. Gaz. 113:310-322.

Hanisch ten Cate, C.H.H. and J. Bruinsma. 1973. Abscission of flower bud pedicels in Begonia. I. Effects of plant growth regulating substances on the abscission with intact plants and with explants. Acts. Bet. Neerland. 22:666-674.

Hayes, P.M. and J.W. Patrick. 1985. Photosynthate transport in stems of Phaseolus vulgaris L. treated with gibberellic acid, indole-3-acetic acid or kinetin. Planta. 166:371-379.

Kinet, J. M., D. Hurdebise, A. Parmentier, and R. Stainier. 1978. Promotion of inflorescence development by growth substance treatments to tomato plants grown in insufficient light conditions. J. Amer. Soc. Hort. Sci. 103:724-729.

Mann, L.K. and P.A. Minges. 1949. Experiments on setting fruit with growth-regulating substances on field-grown tomatoes in California. Hilgardia 19:309-337.

Mealor, D. and A. Townshend. 1968. Application of enzyme-catalyzed react ions in trace analysis. I. Determination of mercury and silver by their inhibition of invertase. Talanta 15:747-758.

Morgan, P.W. 1984. Is ethylene the natural regulator of abscission?, p. 231-240. In: Y. Fuchs and E. Chalutz (eds.). Biochemical, physiological and applied aspects of ethylene. Martinus Nijhoff/Junk, The Hague, Netherlands.

Osborne, D.J. and F.W. Went. 1953. Climatic factors influencing parthenocarpy and normal fruit-set in tomatoes. Bet. Gaz. 114:312322.

Reid, M. S., J.L. Paul, M.B. Farhoomand, A.M. Kofranek, and G.L. Staby. 1980. Pulse treatments with silver thiosulfate complex extend the vase life of carnations. J. Amer. Soc. Hort. Sci. 105:25-27.

Riov, J., O. Sagee, and R. Goren. 1984. Effect of ethylene on indole- 3-acetic acid transport, metabolism, and level in leaf tissues of woody plants during abscission, p. 267-276. In: Y. Fuchs and E. Chalutz (eds.). Biochemical, physiological, and applied aspects of ethylene. Martinus Nijhoff/Junk, The Hague, Netherlands.

Sagee, O., J. Riov, and R. Goren. 1990. Ethylene-enhanced catabolism of $\left({ }^{14} \mathrm{C}\right)$ indole-3-acetic acid to indole-3-carboxylic acid in citrus leaf tissues. Plant Physiol. 91:54-60.

Seth, A.K. and P.F. Wareing. 1967. Hormone-directed transport of metabolizes and its possible role in plant senescence. J. Expt. Bot. 18:65-77.

Silveira, H. L., L. Aguilar, A. Leitao, and L. Taborda. 1986. Effects of growth regulators for fruit setting on pepper (Capsicum annuum L.) production. Acts Hort. 191:189-197.

Thaxton, D. R., J. W. Kelly, and J.J. Frett. 1988; Control of Hibiscus rosuchinensis L. bud abscission during shipping. Scientia Hort. 34:131-137.

Van Meeteren, U. and M. de Proft. 1982. Inhibition of flower bud abscission and ethylene evolution by light and silver thiosulphate in Lilium. Physiol. Plant. 56:236-240.

Veen, H. 1987. Use of inhibitors of ethylene action. Acts Hort. 201:213222.

Walsh, C.S. and M. Faust. 1982. AVG increases the yield of young 'Delicious' apple trees. HortScience 17:370-372.

Walsh, C. S., H.J. Swartz, and L.J. Edgerton. 1979. Ethylene evolution in apple following post-bloom thinning sprays. HortScience 14:704-706.

Wien, H.C. 1990. Screening pepper cultivars for resistance to flower abscission: A comparison of techniques. HortScience 25:1634-1636.

Wien, H. C., A.D. Turner, and S.F. Yang. 1989. Hormonal basis for ow light intensity-induced flower bud abscission of pepper. J. Amer. Soc. Hort. Sci. 114:981-985.

Yang, S.F. 1980. Regulation of ethylene biosynthesis. HortScience 15:238-243.

Yelle, S., J.D. Hewitt, N.L. Robinson, S. Damon, and A.B. Bennett. 1988. Sink metabolism in tomato fruit. III. Analysis of carbohydrate assimilation in a wild species. Plant Physiol. 87:737-740. 